\title{
Life Satisfaction Of The Internet And Non-Internet Users In Thailand
}

\author{
Orose Leelakulthanit, National Institute of Development Administration, Thailand
}

\begin{abstract}
Life satisfaction is conceptualized in this study according to the psychological and spiritual characteristics, satisfaction with various domains of life, and the demographic characteristics of individuals living in Thailand. Adult Internet users and non-Internet users in Thailand were interviewed. The Internet users were found to be more satisfied with their lives than the nonInternet users. Multiple regression analyses were conducted and the results showed that the Internet users value optimism, personal health, and self positively, whereas consumption of goods was valued negatively. The non-Internet users value optimism, internal locus of control, and family positively, whereas being moderate and social life were valued negatively. Furthermore, it was found that the Internet users felt they could live their lives in the way they valued, except for the aspect of the consumption of goods. Non-Internet users, on the other hand, felt that they were not able to live their lives in the way they valued, except for the aspect of family and social life.
\end{abstract}

Keywords: Life Satisfaction; Internet; Non-Internet; Thailand

\section{INTRODUCTION}

$\mathrm{n}$ this information age, the Internet has been widely used in the workplace and in people's daily lives, especially in the developed countries. This technology has spread all over the world, including Thailand, and it inevitably exerts an impact on the way people spend their lives. This may lead to the questionable influences of the Internet regarding the values of Thais. In this study, the values of Thais can be viewed from three different perspectives: 1) from the psychological point of view in terms of Thais' optimism, the ability of Thais to adapt to change and their internal locus of control; 2) from the spiritual perspective on the purpose of life and moderation; and 3) from the point of view of the domains of life, including family life, social life, work life, personal health, recreation, self, consumption of goods, material possessions, and access to news and information. The culture of Thais, in terms of values, would be pointless if it did not contribute to people's well-being. People should be able to live their lives in ways they value satisfactorily. This study will measure Thais' well-being in terms of life satisfaction because it is more long-term oriented as compared to happiness. It will also investigate the impact of technology on Thais' values by comparing life satisfaction and its determinants among Internet users versus non-Internet users.

\section{LITERATURE REVIEW}

\section{Optimism}

Optimism refers to an individual having positive expectations about the future, whereas pessimism represents the negative expectations of the individual regarding his/her future (Carver and Scheier, 2005). When optimists and pessimists encounter similar events, the optimistic individual tends to be able to cope with negative outcomes in a more effective way (Seligman, 2006). Optimism has been found to be significantly correlated with life satisfaction among adolescents (Roysamb and Strype, 2002), college students (Ayyash-Abdo and Alamuddin, 2007), and the elderly (Isaacowitz, 2005). Thus, Thais that are optimists are assumed to be more satisfied with their lives than pessimists regardless of their use of the Internet. 


\section{Adapting to Change}

Adaptation can be defined as "the process of adjusting oneself to fit a situation or environment" (Yeats, Folts and Knapp, 2000, p. 566). Several studies have found that life changes that are adverse or stressful reduce the individual's quality of life or increase the individual's distress (Aneshensel, 1992; Mirowsky and Ross, 2003). Adverse changes involve loss, death, failure, conflict, and hindrance as in unemployment, demotion, and salary cuts (Podsakoff et al., 2007). In view of adaptation theory (Arthaud-Day and Near, 2005; Hischka and Mau, 2005), another condition for the impact of social change on the individual's quality of life is the individual's shortage of resources in adapting to the impact of the social change. According to this theory, an individual can adapt to change in order to sustain his or her quality of life over time. However, adaptation depends on the availability of resources. Vulnerability caused by a lack of resources will create adverse effects of stress on people's quality of life (Thoits, 2006). When one has ample resources, stress, life change, or social changes are likely to be bearable. In this study, it is assumed that people who can adapt to a changing environment will be satisfied with their lives more than those who cannot, regardless of the use of the Internet.

\section{Internal Locus of Control}

The concept of locus of control refers to the general expectation that behavior, as well as events, are controlled by internal or external forces (Rotter, 1966). The "internals" believe that their own actions control their lives whereas the "externals" believe that control of life comes from outside themselves, so they attribute behavior and events to luck and chance (Seligman, 1973). Previous research has revealed that internal locus of control is consistently related to greater life satisfaction (Klein et al., 1989; Lewinsohn et al., 1991; Morganti et al., 1988; Schulz et al., 1987), higher subjective well-being (Emmons and Diener, 1985), and happiness (Diener, 1984). Moreover, some researchers have demonstrated that locus of control is a powerful predictor of life satisfaction, with its predictive power ranging from $4.6 \%$ to $23 \%$ (Klein et al., 1989; Schulz et al., 1987). Thus, it can be assumed that internal locus of control will be positively related to life satisfaction regardless of the use of the Internet.

\section{Purpose of Life}

Purpose of life is important in and of itself. People are primarily motivated to maximize the meaningfulness of their lives, not their affect. The heightened affect is often, but not always, a by-product or consequence of attempts to maximize meaning. Purpose of life has been found to be the best predictor of satisfaction with life. In predicting life satisfaction, purpose in life provides a buffering effect for lower levels of mood. People with a high purpose in life report high levels of life satisfaction, even with moderate levels of mood. Life satisfaction has been predicted significantly according to purpose in life, even after controlling for physical pleasure and affect balance (Diener et al., 2012). In this study, it is assumed that purpose of life is positively correlated with life satisfaction, regardless of the use of the Internet.

\section{Moderation}

Spiritual life tends to play a significant role in life satisfaction. Unfortunately, general satisfaction with the spiritual life of Thais was found to be negatively correlated with life satisfaction (Leelakulthanit, Day and Walters, 1991). Therefore, this study will drop the measure of general spiritual life and replace it with the belief in moderation in Buddhism. It should be noted that most Thais are Buddhists. They are expected to follow the "Middle Way", which is the path of moderation. A Buddhist is supposed to neither live in luxury (or pursue self-indulgence) nor become an ascetic monk (or pursue self-mortification). This method is sometimes translated as the Middle Path. If you let yourself, you can drive everything to the extreme. Usually that is not a good idea. Even the pleasant things in life become hazardous when applied excessively - excessive eating can lead to obesity, excessive dieting to anorexia, excessive partying to empty pockets, excessive working to stress, excessive traveling to alienation of loved ones, and excessive home-boundness to boredom. The art of living may well lie in finding the right balance between all extremes. In fact, successful living could be defined as applying the right degree of moderation. Thus, it is assumed that moderation is positively correlated with life satisfaction, regardless of the use of the Internet. 


\section{Domains of Life}

From the part-whole perspective, life can be broken down into various domains. It follows that life satisfaction will be determined by the satisfaction with its various domains of life. A major study of life satisfaction in Thailand following this concept found that life satisfaction of Thais was positively influenced by the satisfaction with family, material possessions, and self (Leelakulthanit, Day and Walters, 1991). Thus, these domains of life will be retained in this study, along with some other domains, including social life, work life, personal health, recreation and consumption of goods. It should be noted that in this study, the domain of consumption of goods has been changed from the focus on the functional values of shopping in the earlier study to many more values connection with shopping, including convenience, economic value, and emotional value. Furthermore, this study adds the domain of access to the news and information, which is supposed to play a vital role in people's lives in the information age as well. In short, it is assumed that satisfaction with family, social life, work, personal health, recreation, self, consumption of goods, material possessions, and access to news and information is positively correlated with the life satisfaction of Thais regardless of their use of the Internet.

\section{METHODS}

\section{Sampling}

The questionnaire was first tested with a group of 44 MBA students, followed by personal interviews with a random sample of 44 non-Internet users who were at least 18 years of age and 44 Internet users at least 18 years of age that had at least one year of experience using the Internet. The questionnaire was assessed for its suitability, readability, and possible ambiguity and was revised based on the feedback received from both groups. The main study was conducted by interviewing 220 eligible non-Internet users and 220 other eligible Internet users through convenience sampling mostly in Bangkok. The response rate was $64 \%$.

\section{Respondents}

Comparatively, the respondents from the Internet user group were younger. Sixty-two percent of them were younger than 30 years of age, whereas only $21 \%$ of the non-Internet users were the same age (Table 1). Moreover, the Internet users were mostly never married (72\%) as compared to only $35 \%$ never married in the non-Internet user group. Furthermore, the Internet user group was better educated. Specifically, $91 \%$ of them were at least college graduates, whereas only $22 \%$ of the non-Internet users had graduated from college. The respondents of both groups were mostly employed. Additionally, the Internet users were much richer. Seventy-one percent of them had a monthly household income of at least 45,000 Baht, whereas only $32 \%$ of the non-Internet users had the same level of monthly household income.

\section{Measures}

The scale used to measure life satisfaction and satisfaction with domains of life was similar to that used in the study of Leelakulthanit, Day, and Walters (1991). However, optimism, purpose of life, adaptation to change, internal locus of control, and moderation were measured with a modified seven-point Likert scale $(1=$ strongly agree, $7=$ strongly disagree). The multi-item measures used for all of the constructs in this research were highly valid and reliable, as shown in Appendix 1.

\section{Data Analysis}

In order to attain the unidimensionality of each construct of the multi-item measures, exploratory factor analyses were performed. If the unrotated factor analysis results suggested more than one factor, the items that were weakly related to no factors (factor loadings < .35) or that clearly represented more than a single domain were dropped. The remaining items were refactored until unidimensionality was obtained. Then, reliability analyses, as indicated by Cronbach alphas, were conducted and the reliabilities obtained (in the .7 to .9 range) supported the use of the measures (Nunnally, 1978). The reliabilities reported in the present study (Appendix 1), ranging from .74 to .91 , compared very favorably with those reported in a previous study of life satisfaction, which were in the range of .65 to .88 (Leelakulthanit, Day \& Walters, 1991). 
Table 1: Demographic Profile Of Non-Internet And Internet Users

\begin{tabular}{|c|c|c|}
\hline 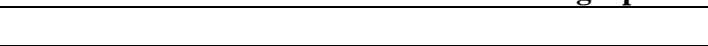 & Non-Internet Users & Internet Users \\
\hline \multicolumn{3}{|l|}{ Gender } \\
\hline Male & $48 \%$ & $47 \%$ \\
\hline Female & $52 \%$ & $53 \%$ \\
\hline \multicolumn{3}{|l|}{ Age } \\
\hline Under 25 & $8 \%$ & $26 \%$ \\
\hline $25-29$ & $13 \%$ & $36 \%$ \\
\hline $30-34$ & $11 \%$ & $14 \%$ \\
\hline $35-44$ & $19 \%$ & $12 \%$ \\
\hline $45-54$ & $27 \%$ & $8 \%$ \\
\hline $55-64$ & $17 \%$ & $4 \%$ \\
\hline 65 and over & $5 \%$ & $1 \%$ \\
\hline \multicolumn{3}{|l|}{ Marital Status } \\
\hline Married & $58 \%$ & $25 \%$ \\
\hline Never married & $35 \%$ & $72 \%$ \\
\hline Not - married (i.e., widowed, divorced, separated) & $7 \%$ & $3 \%$ \\
\hline \multicolumn{3}{|l|}{ Education } \\
\hline Up to upper primary school & $22 \%$ & $1 \%$ \\
\hline Lower secondary school & $18 \%$ & $1 \%$ \\
\hline Upper secondary school & $14 \%$ & $5 \%$ \\
\hline Some college & $24 \%$ & $3 \%$ \\
\hline College graduate & $21 \%$ & $67 \%$ \\
\hline Advanced degree & $1 \%$ & $24 \%$ \\
\hline \multicolumn{3}{|l|}{ Employment Status } \\
\hline Employed & $86 \%$ & $80 \%$ \\
\hline Unemployed & $3 \%$ & $1 \%$ \\
\hline Not employed (i.e., retired, housewife, student) & $11 \%$ & $19 \%$ \\
\hline \multicolumn{3}{|l|}{ Monthly household income } \\
\hline Up to 20,999 & $38 \%$ & $6 \%$ \\
\hline $21,000-26,999$ & $8 \%$ & $6 \%$ \\
\hline $27,000-35,999$ & $12 \%$ & $10 \%$ \\
\hline $36,000-44,999$ & $10 \%$ & $8 \%$ \\
\hline 45,000 or more & $32 \%$ & $71 \%$ \\
\hline
\end{tabular}

\section{RESULTS}

According to the t-test, Internet users are more satisfied with their lives than the non-Internet users. The mean life satisfaction of the Internet user group was 2.82 as compared to 3.20 for the non-Internet user group on the average life satisfaction scale of 7.5 .

The impact of the psychological characteristics of optimism, the ability of Thais to adapt to change and internal locus of control, the spiritual characteristics of purpose of life and moderation, satisfaction with the domains of life, and the demographic characteristics of life satisfaction were investigated by performing multiple regression analyses on both the Internet user group and the non-Internet user group. The values obtained from the scale items of optimism, purpose of life, adaptation to change, internal locus of control, moderation, and the subdomains associated with a particular domain of life and life satisfaction were averaged to form the measures of these constructs. Age was divided into two groups - the respondents who were at least 29 years old and those who were 30 years old or older. Education was categorized into two groups - those with an education lower than a bachelor degree and those with at least a bachelor degree. Household income was also divided into two groups by splitting the group at the monthly household income level of 36,000 Baht (\$US $1=30$ Baht). Multiple regression analyses for the Internet user group and non-Internet user group were run by regressing life satisfaction on optimism, purpose of life, adaptation to change, internal locus of control, moderation, satisfaction with nine domains of life, including family, social life, work, personal health, recreation, self, consumption of goods, material possessions and access to 
news and information, and demographic characteristics; namely, gender, age, marital status, education and monthly household income.

The results of the regression for the Internet group, as shown in Table 2, suggested that taken together, the 19 independent variables accounted for 53\% of the variance in life satisfaction (R-square $=.53$ ). In addition, optimism, satisfaction with personal health, and self had a positive influence on life satisfaction, whereas satisfaction with consumption of goods had a negative effect on life satisfaction. This means that the more optimistic people were and the more satisfied they were with their personal health and self, the more they were satisfied with their lives. On the other hand, the more they were satisfied with their consumption of goods, the less they were satisfied with their lives. According to the standardized beta coefficients, satisfaction with personal health tended to be the most influential on life satisfaction followed by satisfaction with self, consumption of goods, and being optimistic, respectively. It should be noted that multicollinearity was not likely a problem because the magnitude of the variance inflation factors associated with each independent variable was far less than ten (Wetherill, Duncombe, Kenward, Köllerström, Paul \&Vowden, 1986).

Table 2: Results Of Multiple Regression Of Life Satisfaction On Its Determinants In The Internet Users Group

\begin{tabular}{|c|c|c|c|c|c|c|c|}
\hline \multirow[t]{2}{*}{ Model } & \multicolumn{2}{|c|}{ Unstandardized Coefficients } & \multirow{2}{*}{$\begin{array}{c}\begin{array}{c}\text { Standardized } \\
\text { Coefficients }\end{array} \\
\text { Beta } \\
\end{array}$} & \multirow[b]{2}{*}{$\mathbf{t}$} & \multirow[b]{2}{*}{ Sig. } & \multicolumn{2}{|c|}{ Collinearity Statistics } \\
\hline & B & Std. Error & & & & Tolerance & VIF \\
\hline \begin{tabular}{|l|l|}
1 & (Constant)
\end{tabular} & .504 & .619 & & .814 & .417 & & \\
\hline Optimistic & .206 & .102 & .173 & 2.019 & $.045^{*}$ & .452 & 2.212 \\
\hline Purpose & -.081 & .093 & -.079 & -.866 & .388 & .403 & 2.482 \\
\hline Adapt & .052 & .118 & .042 & .439 & .661 & .368 & 2.717 \\
\hline Control & .117 & .121 & .087 & .967 & .335 & .412 & 2.428 \\
\hline Moderate & .071 & .060 & .080 & 1.172 & .243 & .713 & 1.402 \\
\hline Family & .065 & .085 & .068 & .768 & .444 & .428 & 2.338 \\
\hline Social & -.054 & .099 & -.048 & -.541 & .590 & .418 & 2.393 \\
\hline Work & .034 & .090 & .034 & .376 & .707 & .400 & 2.501 \\
\hline Health & .254 & .057 & .321 & 4.443 & $.000 *$ & .633 & 1.579 \\
\hline Recreation & -.036 & .093 & -.036 & -.385 & .701 & .375 & 2.668 \\
\hline Self & .294 & .120 & .251 & 2.458 & $.015^{*}$ & .317 & 3.150 \\
\hline Consumption & -.175 & .084 & -.189 & -2.092 & $.038 *$ & .404 & 2.477 \\
\hline Mat. Possn. & .110 & .095 & .109 & 1.157 & .249 & .372 & 2.688 \\
\hline Information & .102 & .092 & .106 & 1.113 & .268 & .363 & 2.752 \\
\hline Gender & -.111 & .114 & -.065 & -.976 & .331 & .736 & 1.359 \\
\hline Age & .221 & .130 & .131 & 1.705 & .090 & .561 & 1.784 \\
\hline Marry & .033 & .140 & .018 & .237 & .813 & .552 & 1.811 \\
\hline Education & -.003 & .219 & -.001 & -.012 & .991 & .834 & 1.198 \\
\hline Income & -.170 & .130 & -.084 & -1.313 & .191 & .802 & 1.247 \\
\hline $\mathrm{R}^{2}=.53$ & $\mathrm{~F}_{19,141}$ & $\mathrm{P}=.000$ & $*=$ Significa & $\alpha \leq .05$ & & & \\
\hline
\end{tabular}

The results of the regression for the non-Internet group, as shown in Table 3, indicated that taken together, the 19 independent variables accounted for $53 \%$ of the variance in life satisfaction (R-square $=.53$ ). Furthermore, optimism, internal locus of control, and satisfaction with family had a positive influence on life satisfaction, whereas being moderate and satisfaction with social life had a negative impact on life satisfaction. That is to say, the more optimistic, the more in control, and the more satisfied people were with their families, the more they were satisfied with their lives. Contrarily, the more people were being moderate and the more they were satisfied with their social lives, the less they were satisfied with their lives. According to the standardized beta coefficients, satisfaction with family affected life satisfaction the most, followed by optimism, locus of control, and being moderate and satisfied with social life, respectively. It should be noted that optimism and locus of control are equally important.

It is noteworthy that multicollinearity was not likely a problem because the magnitude of variance inflation factors in relation to each independent variable was far less than ten (Wetherill, Duncombe, Kenward, Köllerström, Paul \&Vowden, 1986). 
Table 3: Results Of Multiple Regression Of Life Satisfaction On Its Determinants In The Non-Internet Users Group

\begin{tabular}{|c|c|c|c|c|c|c|c|}
\hline \multirow[t]{2}{*}{ Model } & \multicolumn{2}{|c|}{ Unstandardized Coefficients } & \multirow{2}{*}{$\begin{array}{c}\begin{array}{c}\text { Standardized } \\
\text { Coefficients }\end{array} \\
\text { Beta }\end{array}$} & \multirow[b]{2}{*}{$\mathbf{t}$} & \multirow[b]{2}{*}{ Sig. } & \multicolumn{2}{|c|}{ Collinearity Statistics } \\
\hline & \begin{tabular}{|c|c|}
$\mathbf{B}$ & \\
\end{tabular} & Std. Error & & & & Tolerance & VIF \\
\hline \begin{tabular}{|l|l|}
1 & (Constant) \\
\end{tabular} & .442 & .584 & & .758 & .450 & & \\
\hline Optimistic & .210 & .081 & .194 & 2.583 & $.011 *$ & .553 & 1.809 \\
\hline Purpose & .041 & .091 & .036 & .457 & .649 & .492 & 2.034 \\
\hline Adapt & .024 & .130 & .018 & .188 & .851 & .345 & 2.896 \\
\hline Control & .240 & .110 & .194 & 2.180 & $.031 *$ & .397 & 2.520 \\
\hline Moderate & -.178 & .074 & -.183 & -2.415 & $.017 *$ & .547 & 1.828 \\
\hline Family & .217 & .088 & .214 & 2.473 & $.014 *$ & .419 & 2.384 \\
\hline Social & -.201 & .097 & -.166 & -2.074 & $.040 *$ & .491 & 2.035 \\
\hline Work & .022 & .088 & .022 & .254 & .800 & .409 & 2.445 \\
\hline Health & .072 & .057 & .083 & 1.264 & .208 & .729 & 1.372 \\
\hline Recreation & .067 & .091 & .055 & .733 & .465 & .558 & 1.792 \\
\hline Self & .197 & .115 & .173 & 1.721 & .087 & .311 & 3.211 \\
\hline Consumption & .021 & .076 & .023 & .283 & .777 & .477 & 2.095 \\
\hline Mat. Possn. & .139 & .108 & .136 & 1.282 & .202 & .277 & 3.608 \\
\hline Information & .094 & .069 & .094 & 1.357 & .177 & .648 & 1.544 \\
\hline Gender & -.150 & .115 & -.085 & -1.298 & .196 & .734 & 1.362 \\
\hline Age & .052 & .148 & .026 & .354 & .724 & .605 & 1.654 \\
\hline Marry & .178 & .137 & .099 & 1.297 & .197 & .542 & 1.844 \\
\hline Education & .201 & .140 & .092 & 1.436 & .153 & .765 & 1.307 \\
\hline Income & -.162 & .123 & -.090 & -1.315 & .190 & .667 & 1.499 \\
\hline $\mathrm{R}^{2}=.53$ & $F_{19,151}=8.85$ & $\mathrm{P}=.000$ & $*=$ Signific & $\alpha \leq .05$ & & & \\
\hline
\end{tabular}

In order to assess whether the Internet users could live their lives in a way that they valued satisfactorily, the mean differences of satisfaction with the significant determinants of life satisfaction of the Internet users were compared with those of the non-Internet users. The results from Table 4 reveal that, generally, Internet users can live their lives in the ways they value, except for the aspect of the consumption of goods. According to the t-test, Internet users are more optimistic and more satisfied with self and consumption of goods, but equally satisfied with personal health at $\alpha \leq .05$. It should be noted that although the Internet users were more satisfied with their consumption of goods than the non-Internet users, satisfaction with their consumption of goods contributed negatively to the life satisfaction of the Internet users.

Table 4: Mean Difference In The Significant Determinants Of Life Satisfaction Of The Internet Users Between The Two Groups Of Respondents Based On Use Of The Internet

\begin{tabular}{|l|c|c|c|c|}
\hline \multirow{2}{*}{$\begin{array}{c}\text { Determinant of Life } \\
\text { Satisfaction }\end{array}$} & Non-Internet Users & Mean Score & \multicolumn{2}{c|}{ t-test } \\
\cline { 2 - 5 } & 2.62 & 2.35 & 3.58 & Significant \\
\hline Optimistic & 2.82 & 2.64 & 1.81 & $0.00^{*}$ \\
\hline Personal Health & 2.91 & 2.55 & 4.97 & 0.07 \\
\hline Self & 3.10 & 2.78 & 3.77 & $0.00^{*}$ \\
\hline Consumption & \multicolumn{2}{|c|}{$0.00^{*}$} \\
\hline
\end{tabular}

$*$ = Significant at $\alpha \leq .05$

Likewise, in order to evaluate whether the non-Internet users could live their lives in a way they valued satisfactorily, the mean differences in satisfaction with the significant determinants of life satisfaction of the nonInternet users were compared with the Internet users. The results from Table 5 indicate that, generally, the nonInternet users could not live their lives in a way they valued, except for the aspect of family and social life. According to the t-test, the non-Internet users were as moderate and satisfied with their families as the Internet users. However, they were less optimistic, in control, and less satisfied with their social lives. It is noteworthy that although the non-Internet users were less satisfied with their social lives than the Internet users, satisfaction with this aspect of life happened to contribute negatively to the life satisfaction of the non-Internet users. 
Table 5: Mean Difference In The Significant Determinants Of Life Satisfaction Of The Non-Internet Users Between The Two Groups Of Respondents Based On Use Of The Internet

\begin{tabular}{|l|c|c|c|c|}
\hline \multirow{2}{*}{$\begin{array}{c}\text { Determinant of Life } \\
\text { Satisfaction }\end{array}$} & \multicolumn{2}{|c|}{ Mean Score } & \multicolumn{2}{c|}{ t-test } \\
\cline { 2 - 5 } & Non-Internet Users & Internet Users & t-value & $0.00^{*}$ \\
\hline Optimistic & 2.62 & 2.35 & 4.58 & $0.00^{*}$ \\
\hline Focus of control & 2.68 & 2.36 & -1.14 & 0.26 \\
\hline Moderation & 2.54 & 2.65 & 1.57 & 0.12 \\
\hline Family & 2.60 & 2.47 & 4.54 & $0.00^{*}$ \\
\hline Social Life & 2.94 & 2.62 & & \\
\hline
\end{tabular}

$*=$ Significant at $\alpha \leq .05$

\section{DISCUSSION}

Satisfaction with consumption of goods exerted an adverse effect on the life satisfaction of the Internet users. The reason underlying this phenomenon may be that the more benefits they gained from shopping, whether it was convenience, economic value, or emotional value, the more the likelihood of their addiction to shopping would be. This addiction was likely to make people less happy or less satisfied with their lives.

Being moderate tended to play a negative role in the lives of the non-Internet users. Somehow, the nonInternet users who were not as rich as others did not often buy luxury goods, did not do anything beyond their means, did not believe that the more material possessions the better, and believed in the sufficiency of even having a little were less satisfied with their lives as compared to the ones who felt the opposite. It is noteworthy that the nonInternet users generally had a lower monthly household income than the Internet users (Table 1). This group of people seemed to be limited by their financial resources to only the necessities, whereas the consumption like others, for instance buying luxury products in order to symbolize their status, may be what they want. This contradictory phenomenon makes the non-Internet users less satisfied with their lives than the Internet users.

The impact of the Internet on the changes in the Thai culture - from a family-oriented culture to a selforiented culture - can be evidenced by the two phenomena. First longitudinally - in the past two decades when there was no Internet in Thailand, the Thai people valued family more than self (Leelakulthanit, Day \& Walters, 1991). However, in this study, it was found that the Internet users valued self but not family. Second, in the cross-section analysis of this study, the Internet users appeared to value self but not family, whereas the non-Internet users valued family but not self.

The model of determinants of life satisfaction of the Internet users and non-Internet users in this study can explain the variance in the life satisfaction of Thais much better than the model used by Leelakulthanit, Day \& Walters in their earlier study (1991). Specifically, the R-squares of the model for Internet and non-Internet users were equal at 0.53 , whereas the R-square of an earlier model was at 0.28 .

\section{IMPLICATIONS}

Since Internet users are more satisfied with their lives than non-Internet users, it may be better to have computers and to be connected with the Internet and use it. This argument is in line with the government policy of one tablet per child. According to this policy, the government will give a free tablet computer to every prathom1 (grade 1) student. This policy will guarantee that every grade 1 student, no matter how poor he or she is, will be able to have a tablet computer, which is convenient for the children to carry. Additionally, free loaded e-books and free Internet connection will likely come about with another proposed policy - free wi-fi. The tablet computers are distributed freely to the prathom 1 students who are in the earliest days of their student lives, possibly because the government wants to achieve a long-lasting effect, and with a tablet computer, the students can learn from it and make use of it early in their lives.

The group that deserves the government's attention in heightening their life satisfaction is the elderly, who are mostly non-Internet users since they did not grow up with Internet technology. These retired people generally have more time and, as they get older, they are less energetic and mobile. Thus, their lives tend to be more centered 
at home. These elderly people still want to be well-informed and connected. If the government gives them free tablet computers and massive training in computer skills, they will be able to get access to various information through the Internet, whether it be news, healthcare, cooking, gardening, or any information of their interest. Moreover, with a computer, they can stay connected with their relatives and friends without having to travel that often.

If the government wants to do one thing in order to increase the life satisfaction of both Internet users and non-Internet users, it is the enhancement of the optimism of Thais. This is because optimism was seen to be a significant determinant of life satisfaction for both Internet users and non-Internet users. The Thai government can enhance the optimism of its citizens by adopting several strategies; for instance, public relations strategies or through education and training strategies.

To bridge the gap in life satisfaction between the non-Internet user group and the Internet user group, the non-Internet user group should be able to live their lives in a way they value better than they do now as compared to the Internet user group. Specifically, the notion of the internal locus of control and moderation should be promoted among the non-Internet users who are generally less well-educated and poorer than the Internet users. To encourage this internal locus of control, the government should empower the non-Internet users who are far behind the Internet users in terms of technology. Furthermore, for the time being, the notion of moderation still contributes negatively to the life satisfaction of the non-Internet users; that is to say, it works against their life satisfaction. Thus, the government should find a way, either through public relations or education and training, to instill the proper spirit of moderation in the minds of the non-Internet users.

\section{CONCLUSION}

The Internet users in this study were found to be more satisfied with their lives than the non-Internet users. For the Internet user group, optimism, satisfaction with personal health, and self had a positive influence on life satisfaction, whereas satisfaction with consumption of goods had a negative effect on life satisfaction. In the nonInternet user group, optimism, internal locus of control, and satisfaction with family had a positive influence on life satisfaction, whereas being moderate and satisfaction with social life had a negative impact on life satisfaction. Generally, Internet users are able to live their lives in ways they value, except for the aspect of the consumption of goods. Non-Internet users cannot live their lives in ways they value, except for the aspect of family and social life.

\section{AUTHOR INFORMATION}

Orose Leelakulthanit, $\mathrm{Ph} . \mathrm{D}$. is an associate professor of marketing at National Institute of Development Administration, NIDA Business School, 118 Seri Thai Road, Bangkok 10240, Thailand. Her research interest is in quality of life and customer values. E-mail: orose@nida.ac.th

\section{REFERENCES}

1. Aneshensel, C. S. (1992). Social stress: Theory and research. Annual Review of Sociology, 18, 15-38.

2. Arthaud-Day, M. L., \& Near, J. P. (2005). The wealth of nations and the happiness of nations: Why accounting matters. Social Indicators Research, 74, 511-548.

3. Ayyash-Abdo, H., \& Alamuddin, R. (2007). Predictors of subjective well-being among college youth in Lebanon. The Journal of Social Psychology, 147(3), 265-284.

4. Carver, C. S., \& Scheier, M. F. (2005). Optimism. In C. R. Snyder \& S. J. Lopez (Eds.), Handbook of positive psychology (pp. 182-204). NC: Oxford University Press.

5. $\quad$ Diener, E. (1984). Subjective well-being. Psychological Bulletin, 95, 542-575.

6. Diener, Ed, Fujita, Frank, T. L., \& Biswas-Diener, Robert. (2012). Purpose, mood, and pleasure in predicting satisfaction judgments, Social Indicators Research, 105(3), 333-341.

7. Emmons, R. A., \& Diener, E. (1985). Personality correlates of subjective well-being. Personality and Social Psychology Bulletin, 11, 89-97.

8. Hischka, D., \& Mau, S. (2005). Social anomie and racial segregation in South Africa. Social Indicators Research, 76, 467-498. 
9. Isaacowitz, D. M. (2005). Correlates of well-being in adulthood and old age: A tale of two optimisms. Journal of Research in Personality, 39, 224-244.

10. Klein, M. A., Tatone, A. L. \& Lindsay, N. B. (1989). Correlates of life satisfaction among military wives. The Journal of Psychology, 123, 465-475.

11. Leelakulthanit, O., Day, R., \& Walters, R. (1991). Investigating the relationship between marketing and overall satisfaction with life in a developing country. Journal of Macromarketing, 11(1), 3-23.

12. Lewinsohn, P. M., Redner, J. E., \& Seeley, J. R. (1991). The relationship between life satisfaction and psychosocial variables: New perspectives. In F. Strack, M. Argyle, \& N. Schwarz (Eds.), Subjective wellbeing: An interdisciplinary perspective (pp. 141-169). Oxford, England: Pergamon Press.

13. Mirowsky, J., \& Ross, C. E. (2003). Social causes of psychological distress. New York: Aldine de Gruyter.

14. Morganti, J. B., Nehrke, M. F., Hulicka, I. M. \& Cataldo, J. F. (1988). Life-span differences in life satisfaction, self-concept, and locus of control. International Journal of Aging and Human Development, 26, 45-56.

15. Nunnally, J. (1978). Psychometric Theory (2nd ed.). New York: McGraw-Hill.

16. Podsakoff, N. P., LePine, J. A., \& LePine, M. A. (2007). Differential challenge stressor, hindrance stressor relationships with job attitudes, turnover intention, turnover, and withdrawal behavior. The Journal of Applied Psychology, 92(2), 438-454.

17. Roysamb, E., \& Strype, J. (2002). Optimism and pessimism: Underlying structure and dimensionality. Journal of Social and Clinical Psychology, 21(1), 1-19.

18. Schulz, R., Tompkins, C. A., Wood, D., \& Decker, S. (1987). The social psychology of caregiving: Physical and psychological cost of providing support to the disabled. Journal of Applied Social Psychology, 17, 401-428.

19. Seligman, M. E. P. (1973). Fall into helplessness. Psychology Today, 7, 43-48.

20. Seligman, M. E. P. (1990). Learned optimism: How to change your mind and your life. New York: Simon \& Schuster.

21. Thoits, P. A. (2006). Personal agency in the stress process. Journal of Health and Social Behavior, 47(4), 309-323.

22. Wetherill, G. B., Duncombe, P., Kenward, M., Köllerström, J., Paul, S. R., \& Vowden, B. J. (1986). Regression analysis with applications. New York: Chapman and Hall.

23. Yeats, D. E., Folts, W. E., \& Knapp, J. (2000). Older workers' adaptation to a changing workplace: Employment issues for the 21st century. Educational Gerontology, 26, 565-582. 


\section{APPENDIX 1}

\begin{tabular}{|c|c|}
\hline \multicolumn{2}{|l|}{ Dimensionality and Internal Consistency of Measures } \\
\hline Determinants of Life Satisfaction & Factor Loading \\
\hline \multicolumn{2}{|l|}{ 1. Life in General } \\
\hline Delighted - Terrible Scale & 0.81 \\
\hline Faces Scale & 0.79 \\
\hline Satisfaction Scale & 0.79 \\
\hline Ladder Scale & 0.76 \\
\hline Variance Explained & $62.15 \%$ \\
\hline Coeff. Alpha & 0.79 \\
\hline \multicolumn{2}{|l|}{ 2. Optimism } \\
\hline You are an optimist. & 0.79 \\
\hline You often look at the bright side of your future. & 0.79 \\
\hline You will look at the good side of others and overlook the bad side. & 0.71 \\
\hline When something bad happens you think it will disappear. & 0.70 \\
\hline Variance Explained & $56.00 \%$ \\
\hline Coeff. Alpha & 0.74 \\
\hline \multicolumn{2}{|l|}{ 3. Purpose of Life } \\
\hline You know what the purpose of your life is. & 0.84 \\
\hline You know your own purpose of life. & 0.81 \\
\hline You know why you are living. & 0.80 \\
\hline Even if you have to fight, it is better than not knowing why you are living. & 0.72 \\
\hline You are willing to go through difficulties in order to reach your destination. & 0.72 \\
\hline You can answer right away when you are asked why you were born. & 0.63 \\
\hline Variance Explained & $57.30 \%$ \\
\hline Coeff. Alpha & 0.84 \\
\hline \multicolumn{2}{|l|}{ 4. Adaptation to Change } \\
\hline You can adjust when there are changes. & 0.82 \\
\hline You can learn and apply lessons to changing situations. & 0.80 \\
\hline You have the skill to solve problems. & 0.77 \\
\hline You often have a contingency plan up front in order to cope with the changing environment. & 0.65 \\
\hline If the situation changes you will accept it right away and find a way to face it later. & 0.63 \\
\hline Change is normal. & 0.61 \\
\hline Variance Explained & $51.57 \%$ \\
\hline Coeff. Alpha & 0.80 \\
\hline \multicolumn{2}{|l|}{ 5. Internal Locus of Control } \\
\hline You are free to choose and act in your own way. & 0.78 \\
\hline You are free to express your own opinion. & 0.78 \\
\hline You can manage circumstances. & 0.70 \\
\hline Things that happen to you are from your own actions. & 0.67 \\
\hline You have the opportunity to change the things that you don't like. & 0.67 \\
\hline Any success or failure is up to you. & 0.66 \\
\hline The things that you choose are often based on your values and real interest. & 0.61 \\
\hline You can control your own fate. & 0.60 \\
\hline Variance Explained & $47.27 \%$ \\
\hline Coeff. Alpha & 0.83 \\
\hline \multicolumn{2}{|l|}{ 6. Moderation } \\
\hline Even if you have a little you know what is enough. & 0.86 \\
\hline You rarely do things beyond your capacity. & 0.81 \\
\hline You do not often like to buy luxury products. & 0.80 \\
\hline You do not have to be very rich like others. & 0.75 \\
\hline Having more possessions is not necessarily better. & 0.70 \\
\hline Variance Explained & $61.54 \%$ \\
\hline Coeff. Alpha & 0.84 \\
\hline
\end{tabular}




\section{APPENDIX 1 - Continued}

\begin{tabular}{|c|c|}
\hline Determinants of Life Satisfaction & Factor Loading \\
\hline \multicolumn{2}{|l|}{ 7. Family } \\
\hline Home-life & 0.85 \\
\hline Housing & 0.81 \\
\hline Children & 0.79 \\
\hline Parents, brothers, sisters & 0.73 \\
\hline Marriage & 0.72 \\
\hline Neighborhood & 0.72 \\
\hline Transportation & NA \\
\hline Variance Explained & $59.06 \%$ \\
\hline Coeff. Alpha & 0.86 \\
\hline \multicolumn{2}{|l|}{ 8. Social Life } \\
\hline The chance to spend time with others & 0.83 \\
\hline Your conversations or chats with friends and others & 0.82 \\
\hline Convenient meeting places & 0.78 \\
\hline Clubs and social organization & 0.76 \\
\hline Your neighbors and acquaintances & 0.75 \\
\hline Your friends & 0.70 \\
\hline Variance Explained & $59.84 \%$ \\
\hline Coeff. Alpha & 0.87 \\
\hline \multicolumn{2}{|l|}{ 9. Work } \\
\hline Opportunities for expressing your abilities & 0.88 \\
\hline Advancement of opportunities & 0.84 \\
\hline Autonomy & 0.83 \\
\hline Earning & 0.82 \\
\hline Job security & 0.74 \\
\hline Retirement program & 0.72 \\
\hline Hours worked & 0.72 \\
\hline Availability of work & 0.70 \\
\hline People you work with & 0.65 \\
\hline Working condition & NA \\
\hline Variance Explained & $59.17 \%$ \\
\hline Coeff. Alpha & 0.91 \\
\hline \multicolumn{2}{|l|}{ 10. Personal Health } \\
\hline Stamina & 0.91 \\
\hline Wellness & 0.89 \\
\hline Mobility & 0.88 \\
\hline Appearance & 0.80 \\
\hline Variance Explained & $75.77 \%$ \\
\hline Coeff. Alpha & 0.89 \\
\hline \multicolumn{2}{|l|}{ 11. Recreation } \\
\hline Hobbies & 0.83 \\
\hline Entertainment and cultural events & 0.81 \\
\hline Travelling & 0.78 \\
\hline Spectator sports & 0.71 \\
\hline Computer games & 0.70 \\
\hline Local recreation and fitness facilities & 0.69 \\
\hline Access to planes, trains & NA \\
\hline Variance Explained & $57.06 \%$ \\
\hline Coeff. Alpha & 0.84 \\
\hline
\end{tabular}




\section{APPENDIX 1 - Continued}

\begin{tabular}{|c|c|}
\hline Determinants of Life Satisfaction & Factor Loading \\
\hline \multicolumn{2}{|l|}{ 12. Self } \\
\hline Ability to learn on your own & 0.81 \\
\hline Level of professional competence & 0.81 \\
\hline Respect by others & 0.81 \\
\hline Social skills & 0.79 \\
\hline Self-actualization & 0.73 \\
\hline Confidence in yourself & 0.73 \\
\hline Level of education & 0.68 \\
\hline Variance Explained & $59.09 \%$ \\
\hline Coeff. Alpha & 0.88 \\
\hline \multicolumn{2}{|l|}{ 13. Consumption of Goods } \\
\hline Shopping gives you enjoyment. & 0.88 \\
\hline Shopping makes you relax. & 0.88 \\
\hline Shopping is a chance to do things with family and friends. & 0.83 \\
\hline The convenience of shopping & 0.76 \\
\hline Online shopping & 0.75 \\
\hline The chance to buy good things cheaply & 0.75 \\
\hline Variance Explained & $65.70 \%$ \\
\hline Coeff. Alpha & 0.90 \\
\hline \multicolumn{2}{|l|}{ 14. Material Possessions } \\
\hline Furniture and appliances & 0.83 \\
\hline House & 0.83 \\
\hline Private transportation & 0.83 \\
\hline Clothing and jewelry & 0.80 \\
\hline Computers & 0.73 \\
\hline Mobile phones & 0.68 \\
\hline Saving and investment & 0.67 \\
\hline Variance Explained & $59.27 \%$ \\
\hline Coeff. Alpha & 0.88 \\
\hline \multicolumn{2}{|l|}{ 15. Information } \\
\hline News and information from newspapers & 0.84 \\
\hline News and information from TV & 0.83 \\
\hline News and information from the Internet & 0.76 \\
\hline News and information from the radio & 0.75 \\
\hline Variance Explained & $63.47 \%$ \\
\hline Coeff. Alpha & 0.81 \\
\hline
\end{tabular}

